\title{
[54] Proteins Mediating Vectorial Translocation: Purification of the Active Domain of the Endoplasmic Reticulum Docking Protein
}

\author{
By DAVID I. MEYER and BERnHARD DOBbERSTEIN
}

Since the discovery that vectorial translocation of nascent secretory proteins can be accomplished in vitro using isolated rough microsomes, ${ }^{1}$ efforts have been underway to dissect out the membrane components that mediate such transport. To date, two approaches have been taken, and two protein components have been isolated. The first approach utilized high-salt treatment to dissociate an essential component from rough microsomes (RM). Salt-washed microsomes were no longer able to translocate nascent secretory proteins synthesized in the wheat germ cell-free syste $^{2}$; however, they retained their ability to translocate proteins in the reticulocyte lysate system. ${ }^{3}$ This latter activity could be subsequently proteolytically released from membranes by elastase and high-salt treatment ${ }^{4}$ In each of these cases, the material removed from the microsomes could be added back to the membranes rendered inactive by the treatment, thereby restoring activity in the appropriate cell-free system.

Subsequent studies determined that a protein complex of $M_{\mathrm{r}} 250,000$ (called signal recognition protein, SRP) was the component liberated by high-salt treatment and required for activity in wheat germ lysate..$^{5}$ Elastase and high salt removed a 60 kilodalton domain (from a 72 kilodalton membrane protein) from salt-washed RM, rendering the membranes inactive in reticulocyte lysate. ${ }^{4}$ The relationship between the two components and their respective activities in the two translation systems is shown in Fig. 1. It is now known that the 72 kilodalton membrane protein is required for the functional association of SRP. ${ }^{6}$ Moreover, evidence has been accumulated demonstrating that SRP may well exert its effect as a soluble component of the cytoplasm. ${ }^{6}$ As the 72 kilodalton membrane protein represents the site at which the ribosomal complex + SRP first makes contact with the endoplasmic reticulum (ER), it has been termed the "docking" protein (DP).

G. Blobel and B. Dobberstein, J. Cell Biol. 67, 852 (1975).

2 G. Warren and B. Dobberstein, Nature (London) 273, 569 (1978).

${ }^{3}$ D. Meyer and B. Dobberstein, J. Cell Biol. 87, 498 (1980).

${ }_{4}^{4}$ D. Meyer and B. Dobberstein, J. Cell Biol. 87, 503 (1980).

5. Walter and G. Blobel, Proc. Natl. Acad. Sci. U.S.A. 77, 7112 (1980).

6 D. Meyer et al., Nature (London) 297, 647 (1982). 


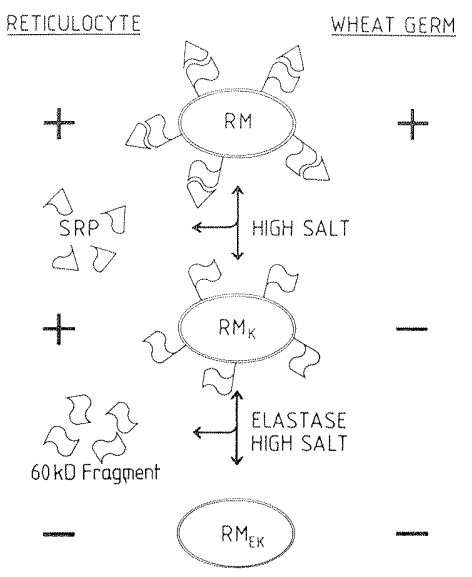

FIG. 1. Dissection and reconstitution of rough microsomes $(R M)$ using protease and high salt. When RM are treated with $0.5 \mathrm{M} \mathrm{KCl}$, translocation activity is lost in wheat germ (due to the saltmediated removal of SRP), and $R M_{K}$ are generated that are nonetheless active in reticulocyte lysate. Treatment of salt-washed microsomes $\left(\mathrm{RM}_{\mathrm{K}}\right)$ with elastase and high salt yields $R M_{E K}$ that are inactive in either system. This is due to the loss of a 60 kilodalton peptide fragment from the docking protein $\left(D_{\mathrm{f}}\right)$. Reconstitution can be achieved sequentially by readdition of $D P_{f}$ to $\mathrm{RM}_{\mathrm{EK}}$ (thus restoring activity in reticulocyte lysate) followed by readdition of SRP to $R M_{\mathrm{EK}}-\mathrm{DP}_{\mathrm{f}}$ membranes. In this way full reconstitution is achieved in both cell-free systems. From Meyer et al. ${ }^{6}$

Presented here are the procedures needed to isolate and purify the active domain of the docking protein from isolated rough microsomes.

\section{Assay System}

The general principle of using dog pancreas microsomes to reconstitute translocation of secretory proteins ${ }^{7}$ must be slightly modified to allow the addition of isolated factors to the system, as well as the membranes.

\section{Components}

Rabbit reticulocyte lysate ${ }^{8}$

Potassium acetate, $1 \mathrm{M}$

Magnesium acetate, $50 \mathrm{mM}$

Rough microsomes (or microsomes + isolated components) in 0.25 $M$ sucrose, $20 \mathrm{~m} M$ HEPES, $50 \mathrm{~m} M \mathrm{KCl}^{7}$

mRNA for a secretory protein, e.g., IgG light chain, preprolactin, human placental lactogen ${ }^{9}$

Translation grade $\left[{ }^{35} \mathrm{~S}\right]$ methionine (specific activity $>1000 \mathrm{Ci} / \mathrm{mmol}$ )

Procedure. Assays are carried out in heat-sterilized microfuge tubes $(1.5 \mathrm{ml})$ at $37^{\circ}$ in a final volume of $25 \mu \mathrm{l}$. The mixture contains $1 \mu \mathrm{l}$ of mRNA $\left(0.1-0.5 \mu \mathrm{g}\right.$ of poly(A)-rich RNA), $4 \mu$ l of $\left[{ }^{35} \mathrm{~S}\right] \mathrm{Met}(\sim 40-50 \mathrm{mCi})$, $0.5 \mu \mathrm{l}$ of $\mathrm{MgAc}(50 \mathrm{mM})$, and $4.5 \mu \mathrm{l}$ of a cocktail consisting of spermidine, creatine phosphate, dithiothreitol (DTT) and GTP. ${ }^{8}$ Five microliters of a

7 P. Walter and G. Blobel, this volume [6].

${ }^{8}$ T. Hunt and R. J. Jackson, this volume [4].

${ }^{9}$ P. M. Lizardi, this volume [3]. 
membrane solution or a mixture of inactive membranes preincubated with fractions to be tested (see below) are added, and the reaction is initiated by the addition of $10 \mu \mathrm{l}$ of nuclease-treated reticulocyte lysate. After $1 \mathrm{hr}$ the samples are cooled and processed for PAGE and fluorography. ${ }^{10}$ Typically $2-4 \mu$ l of the incubation mixture are sufficient.

\section{Quantitation of Activity}

The processing of nascent secretory proteins involves cotranslational cleavage of the signal sequence on the luminal side of microsomal vesicles. The processed nascent chains are known to have been translocated across the membrane and sequestered within microsomal vesicles because they are resistant to proteolytic attack. ${ }^{1}$ Thus the cleavage of the signal sequence is a direct measure of the translocation capability of a membrane. In other words, the ratio of processed secretory protein to the total amount synthesized (authentic + preprotein) can be expressed as percentage of processing.

Values for percentage of processing can be obtained in two ways. Fluorograms can be scanned by densitometric methods and the intensities of the bands of preprotein and authentic protein compared. It is important in this case that the grains of the X-ray film being used are not saturated, i.e., that the film is developed while photon adsorption is occurring linearly. A more precise measurement is obtained when the respective bands are located on the polyacrylamide gel and are cut out and counted directly. Localization of bands can be accomplished fluorometrically (as above) or by staining using appropriate standard proteins.

Whichever method is used, it is essential to take into account alterations in the specific radioactivity that may have occurred during processing. For example, IgG light chain contains five methionine residues in the preprotein and only three in the authentic light chain. Accurate values for percentage of processing must therefore reflect such a change.

Routinely, $2.5 \mu \mathrm{l}$ of inactive RM (see below for method of preparation) are incubated with $2.5 \mu \mathrm{l}$ of the fraction being tested. As the fraction usually has a $[\mathrm{KCl}]=0.5 \mathrm{M}$, and the $\mathrm{RM}$ are in $50 \mathrm{mM} \mathrm{KCl}$, the final $[\mathrm{KCl}]$ of the $5-\mu \mathrm{l}$ sample is $275 \mathrm{mM}$. It is therefore imperative that the cellfree translation system be able to accommodate this addition of $\mathrm{KCl}$. This is easily accomplished by omitting $\mathrm{KAc}$ from the translation mixture. The final $[\mathrm{KCl}]$ when the $5 \mu$ l of $\mathrm{RM}+$ sample are added to the $20 \mu \mathrm{l}$ from the translation system will be about $55 \mathrm{~m} M$, very near the optimum.

${ }_{10} \mathrm{~W}$. M. Bonner, this volume [15]. 


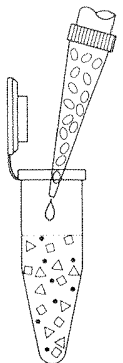

(1)

ADD RMK

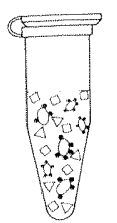

(2)

INCUBATE $30^{\circ}$

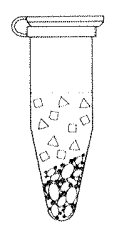

(3)

REMOVE RMK $12,000 \times g 20^{\circ}$

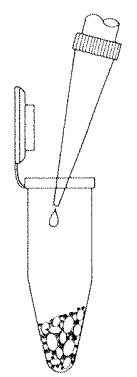

(4)

ADO WHEAT GERM SYSTEM

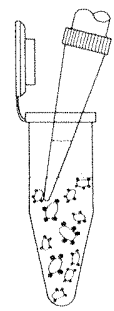

(5)

ASSAY FOR

TRANSLOCATION

FIG. 2. Membrane-affinity factor isolation assay. Inactive rough microsomes are added to samples in order to adsorb activity-restoring factors. (1) In this example, salt-washed rough microsomes $\left(\mathrm{RM}_{\mathrm{K}}\right)$, which are inactive in wheat germ lysate, are added to a solution to be tested for signal recognition protein (SRP) activity under appropriate salt conditions. Elastase-treated, high-salt washed membranes $\left(\mathrm{RM}_{\mathrm{EK}}\right)$ could be used in the same way to test for the presence of docking protein fragment $\left(D P_{f}\right)$ in a given sample. (2) Suspensions are incubated for $30 \mathrm{~min}$ at $0^{\circ}$. (3) The membranes are pelleted by centrifugation at $12,000 \mathrm{~g}$ for $20 \mathrm{~min}$. (4) The appropriate cell-free translation system is added to resuspend the membranes. (5) Translations are assayed for the translocation activity of the reconstituted membranes.

An exquisitely sensitive method for assaying factors involved in translocation has been devised. It makes use of the inactive membrane's ability to adsorb the required components from solution and thus reconstitute activity. In the traditional assay as described, the inactive membranes as well as the fraction to be tested are added to the translation system. As there is only a limited volume of exogenous material that one can add to a cell-free translation, reconstitution is largely dependent on the concentration of the activity-restoring factor in the fraction being tested.

The affinity-based assay (see Fig. 2) allows the sample of membranes, typically $2.5 \mu \mathrm{l}$ at $A_{280}=60 \mathrm{units} / \mathrm{ml}$, to absorb out the active factor from a sample up to 100 times larger than is normally added to a translation. Such a method also allows one to assay for active factors even when there are components present in the fraction that are inhibitory to in vitro protein synthesis (such as protease, ribonuclease, or competing initiation factors).

Method. Inactive RM $(2.5 \mu \mathrm{l})$ at $A_{280}=60$ units $/ \mathrm{ml}$ in membrane buffer are added to the fraction being tested (typically $20-200 \mu \mathrm{l}$ ). The suspension is incubated for $30 \mathrm{~min}$ at $0^{\circ}$ in a $1.5-\mathrm{ml}$ microfuge tube. The sample is then centrifuged for $20-30 \mathrm{~min}$ at $12,500 \mathrm{~g}$ in a microfuge, and the super- 
natant is immediately removed with a syringe needle coupled to an aspirator. The pellet, which is barely visible, is then suspended in the complete cell-free translation system and assayed for reconstitution as indicated above. Such a microbinding assay can be used to measure the presence or levels of SRP in cellular extracts, ${ }^{11}$ or, as in this case, for following the purification of $D P_{\mathrm{f}}$.

\section{Purification of Docking Protein}

All procedures are carried out at $0^{\circ}$ unless specified otherwise.

Step 1. Preparation of Stripped Rough Microsomes. Dog pancreas rough microsomes, prepared by the method described by Blobel, ${ }^{7}$ are first stripped of ribosomes by a combination of EDTA and high-salt treatment. The pelleted RM are suspended to a concentration of $60 A_{280} / \mathrm{ml}$ (measured in $2 \%$ SDS) in $0.25 M$ sucrose, $20 \mathrm{~m} M$ HEPES, pH $7.5,50 \mathrm{mM} \mathrm{KCl}$, $5 \mathrm{~m} M$ DTT (membrane buffer). Using concentrated stock solutions, the [EDTA] is brought to $10 \mathrm{mM}$ and $[\mathrm{KCl}]$ to $0.5 \mathrm{M}$. The suspension is incubated on ice for $15 \mathrm{~min}$ and then layered over a 0.5 volume cushion of $0.75 M$ sucrose, $20 \mathrm{~m} M$ HEPES, pH 7.5 , and $0.5 \mathrm{M} \mathrm{KCl}$ in polycarbonate centrifuge tubes. The material is then centrifuged for $90 \mathrm{~min}$ at 105,000 $g_{\text {av }}$. After centrifugation three fractions are obtained: $(a)$ a tight pellet consisting largely of polysomes; $(b)$ the cushion into which the RM have migrated, which has a milky appearance; and $(c)$ a clear, EDTA-rich upper phase. The upper phase is carefully removed by aspiration and the milky layer is decanted from above the pellet. The milky solution is diluted with two volumes of $20 \mathrm{~m} M$ HEPES in order to reduce the sucrose concentration to $0.25 \mathrm{M}$. This membrane-containing suspension is then centrifuged for 60-90 min at 105,000 $\mathrm{g}_{\mathrm{av}}$ to pellet the stripped RM.

Step 2. Detergent Extraction of Stripped RM. Preliminary studies demonstrated that protease-high salt treatment of RM yielded, in addition to others, two proteins of $M_{\mathrm{r}} 60,000$ whose characteristics were similar enough to complicate purification procedures. One protein is the fragment of the docking protein $\left(\mathrm{DP}_{\mathrm{f}}\right)$, the other a contaminant having no relevant activity. Fortunately, this contaminant can be removed from RM by detergent treatment at low salt concentrations, a condition that allows the docking protein to remain associated with the detergent-insoluble material.

The pellet of stripped RM is suspended to a concentration of $A_{280}=50$ units $/ \mathrm{ml}$ in membrane buffer containing $40 \mu \mathrm{g}$ of phenylmethylsulfonyl fluoride (PMSF) per milliliter. Triton X-100, 20\% (w/v), is added until a

"P. Walter and G. Blobel, this volume [53]. 
final Triton concentration of $1 \%$ is achieved. The membrane suspension is gently agitated and then layered over a cushion of 0.5 volume of $0.5 \mathrm{M}$ sucrose, $20 \mathrm{~m} M$ HEPES, $50 \mathrm{mM} \mathrm{KCl}$. Centrifugation is carried out for 90 min at $105,000 g_{\text {av }}$. The Triton phase, as well as the cushion are aspirated off, and the pellet is resuspended in $0.5 \mathrm{M} \mathrm{KCl}, 20 \mathrm{~m} M$ HEPES, pH 7.5, 5 $\mathrm{m} M$ DTT to a concentration of $A_{280}=50$ units $/ \mathrm{ml}$.

Step 3. Elastase Extraction of Triton-Insoluble Membrane Material. A $1 \%$ solution of elastase (from pig pancreas) is treated with an equal volume of $1 \%$ Trasylol to inactivate nonelastolytic proteolytic activity. The elastase-Trasylol mixture is then added to the membrane solution to a final elastase concentration of $1 \mu \mathrm{g} / \mathrm{ml}$. The suspension is then vigorously shaken at $0^{\circ}$ for $1 \mathrm{hr}$ in a reciprocally shaking ice-water bath. The proteolysis is stopped by the addition of PMSF to a final concentration of $200 \mu \mathrm{g} / \mathrm{ml}$. The insoluble material is removed by centrifugation for $2 \mathrm{hr}$ at $105,000 g_{\text {av }}$, and the resulting supernatant represents the crude elastase extract (EE).

Step 4. Purification of $D P_{f}$ from EE Using Ion-Exchange Chromatography. The fragment released from the docking protein by elastase and high salt is basic in character. For this reason, cation exchangers such as carboxymethyl-Sephadex represent an effective means of purification. The EE is first dialyzed into $200 \mathrm{~m} M \mathrm{KCl} 20 \mathrm{~m} M$ HEPES, $1 \mathrm{~m} M$ DTT. A column is prepared of CM-Sephadex equilibrated with the same buffer. Routinely $1-2 \mathrm{ml}$ of packed CM-Sephadex is more than sufficient to adsorb $\mathrm{DP}_{\mathrm{f}}$ from $10 A_{280}$ units of $\mathrm{EE}$. The dialyzed EE is applied to the column, equipped with a UV monitor set to $280 \mathrm{~nm}$, and the column is washed with the equilibration buffer until no further UV-absorbing material comes off of the column. The $\mathrm{DP}_{\mathrm{f}}$ is then eluted by the addition of 350

\begin{tabular}{|c|c|c|}
\hline Elastase extract $\left(+\mathrm{RM}_{\mathrm{i}}\right)$ & $\begin{array}{l}\text { Specific } \\
\text { activity }^{a}\end{array}$ & $\begin{array}{c}\text { Total } \\
\text { protein }\end{array}$ \\
\hline Crude & 4.4 & 27 \\
\hline After CM-Sephadex & 13.3 & 2.0 \\
\hline After Sephadex G-150 & 320 & 0.05 \\
\hline \multicolumn{3}{|c|}{$\begin{array}{l}\text { a Specific activity is expressed as the reciprocal } \\
\text { of the amount of material (in } A_{280} \text { ) } \times 10^{-3} \\
\text { needed to convert } 50 \% \text { of } \operatorname{IgG} \text { light chain pre- } \\
\text { cursor to authentic light chain in one } 25-\mu l \\
\text { cell-free translation. } \\
{ }^{b} A_{280} \text { units. }\end{array}$} \\
\hline
\end{tabular}


$\mathrm{m} M \mathrm{KCl}, 20 \mathrm{~m} M$ HEPES, $\mathrm{pH} 7.5,1 \mathrm{~m} M$ DTT. The peak thus collected is designated CM-bound EE.

Step 5. Gel Filtration of CM-Bound EE. The products obtained from ion exchange lend themselves well to further purification by gel filtration. Since DP $P_{f}$ has an $M_{r}$ of 60,000 and the major contaminants are of high $M_{\mathrm{r}}$ $(>100,000)$, Sephadex G-150 can be used to purify $D P_{\mathrm{f}}$ to near homogeneity. Typically a $1 \times 25 \mathrm{~cm}$ column is packed with fine Sephadex G-150 and

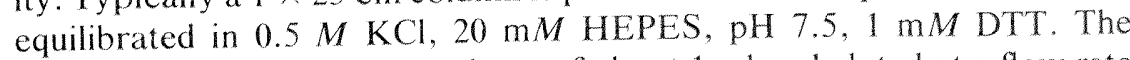
sample is then applied in a volume of about $1 \mathrm{ml}$ and eluted at a flow rate of $1.5 \mathrm{ml} / \mathrm{hr}$. Fractions of $0.5 \mathrm{ml}$ are collected and assayed for activity and protein composition.

\section{Preparation of Inactive Rough Microsomes}

When $D P_{f}$ is prepared from extracts of $R M$ the elastase concentration is crucial. If too much is used, the $\mathrm{DP}_{\mathrm{f}}$ liberated by the protease is also degraded by it. ${ }^{3}$ It was determined that the optimal concentration for release of active $\mathrm{DP}_{\mathrm{f}}$ is not sufficient, in a reasonable period of time, to remove all the DP activity from the membrane. Thus it is necessary to prepare the inactive RM separately from $\mathrm{DP}_{\mathrm{f}}$. Stripped $\mathrm{RM}$ (see below) are suspended in membrane buffer to a concentration of $A_{280}=60$ units/ $\mathrm{ml}$. Protease, either trypsin at $5 \mu \mathrm{g} / \mathrm{ml}$ or elastase at $10 \mu \mathrm{g} / \mathrm{ml}$, is added, and the sample is incubated in an ice-water bath for $60 \mathrm{~min}$ with continual agitation. The reaction is stopped by the addition of PMSF to a final concentration of $200 \mu \mathrm{g} / \mathrm{ml}$. The membranes are pelleted by centrifugation at $105,000 \mathrm{gav}_{\mathrm{av}}$ for $2 \mathrm{hr}$ and then resuspended to a concentration of $A_{280}=$ 60 units $/ \mathrm{ml}$. Such treatment should yield membranes that are capable of translocation to levels of less than $5 \%$. Addition of crude elastase extract (see below) should enable full reconstitution of activity in the reticulocyte lysate system.

\section{Analysis of Purification}

At each stage in the purification scheme, activity measurements and an analysis of protein composition should be undertaken. The most convenient way to express the activity of a given sample is to perform a titration of the fraction, holding the membrane concentration constant, and determine the dilution (or protein concentration) at which $50 \%$ processing can be reconstituted in a standardized assay (see Quantitation of Activity, above). The results of such a purification analysis are shown in the table. 


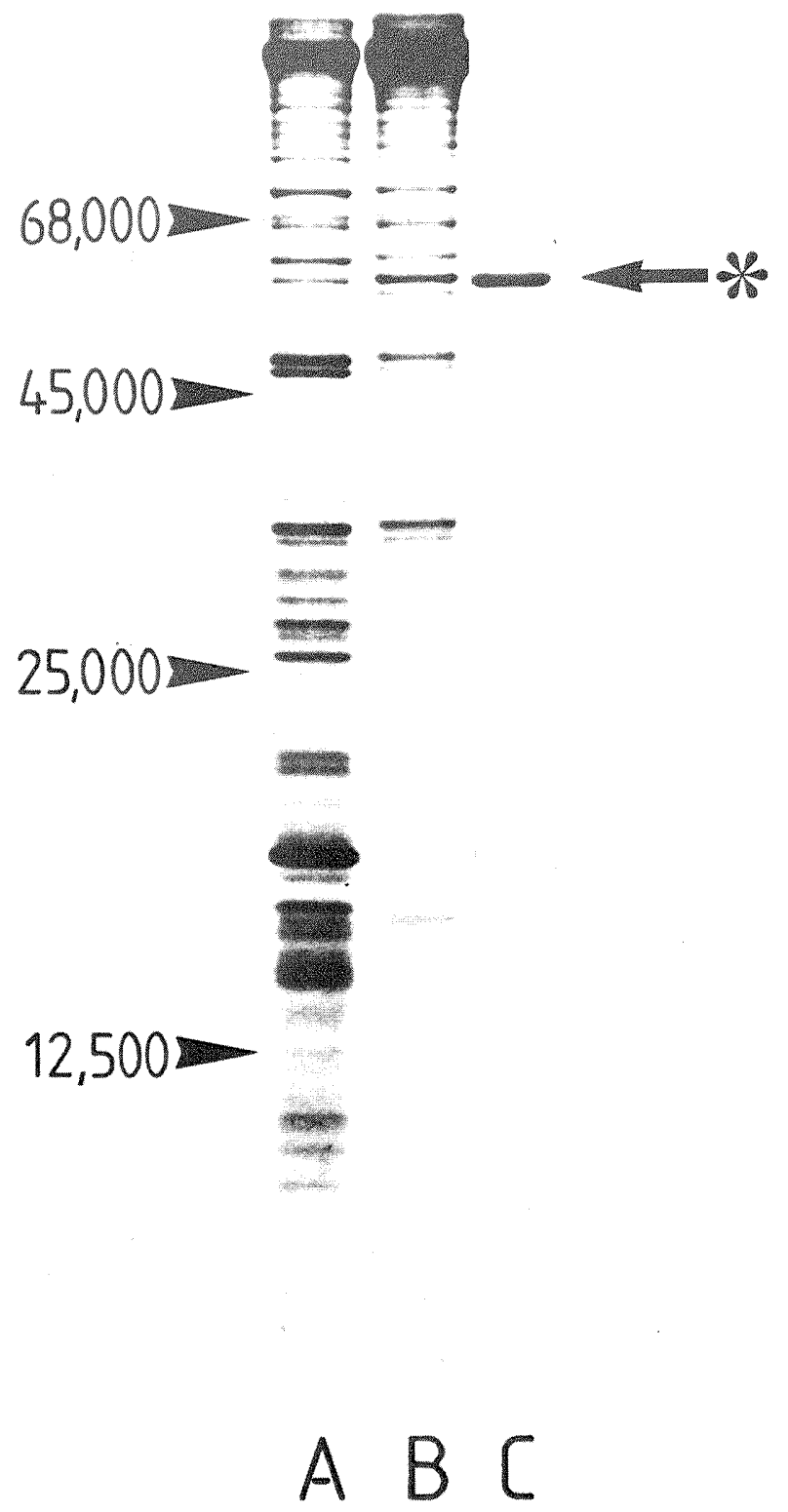

Fig. 3. Purification of material bound to CM-Sephadex by gel filtration. Elastase extract derived from Triton X-100-50 $\mathrm{m} M \mathrm{KCl}$-extracted microsomes was bound to CM-Sephadex at $200 \mathrm{mM} \mathrm{KCl}$ and eluted at $350 \mathrm{mM} \mathrm{KCl}$. The eluted material was concentrated and further fractionated on Sephadex G-150, as described. Elastase extract fractions containing translocation/processing activity were separated on polyacrylamide gels and stained with Coomassie Blue. Lanes: A, elastase-high-salt extract of microsomes (EE); B, material eluted from CM-Sephadex at $350 \mathrm{~m} M \mathrm{KCl} ; \mathrm{C}$, translocation-processing activity-containing fraction obtained by gel filtration on Sephadex G-150. Asterisk-arrow indicates $M_{\mathrm{r}} 60,000$ protein. From Meyer and Dobberstein. ${ }^{4}$ 
The protein composition of fractions is best determined by polyacrylamide gel electrophoresis and staining with either Coomassie Blue or silver. In the case of Coomassie Blue, samples have to be concentrated by trichloroacetic acid precipitation prior to gel electrophoresis. Use of the far more sensitive silver staining procedure ${ }^{12}$ enables visualization of band patterns without prior concentration or precipitation of samples. A summary of a typical purification is seen in Fig. 3.

${ }^{12}$ C. R. Merril, D. Goldman, and M. L. Van Keuren, this volume [17].

\title{
[55] Biosynthesis of Glyoxysomal Proteins
}

\author{
By H. KindL and C. KRUSE
}

Glyoxysomes and other microbodies contain a limited number of constituent proteins; they can, as organelles, easily be surveyed. Enzymes for fatty acid $\beta$-oxidation and glyoxylate cycle, catalase, some enzymes of urate degradation and glycolate pathway are housed in glyoxysomes. ${ }^{1-5}$ The limited number of the components, the single membrane surrounding the organelle, and the fact that the proteins are encoded only by nuclear genes, render glyoxysomes very suitable for studies on the biosynthesis and assembly of an organelle.

\section{Analysis of the Protein Components of Glyoxysomes}

Investigations of the suborganellar location of the glyoxysomal enzymes establish that, in general, a preferential occurrence and organization has to be considered. ${ }^{6-8}$ It is, therefore, practicable to separate the organellar components into three fractions: matrix, peripheral membrane proteins, and integral membrane proteins. Each of these fractions con-

${ }^{1}$ N. E. Tolbert, Annu. Rev. Plant Physiol. 22, 45 (1971).

2 H. Beevers, Annu. Rev. Plant Physiol. 30, 159 (1979).

3 S. E Frederick, P. J. Gruber, and E. H. Newcomb, Protoplasma 84, 1 (1975).

4 B. Gerhardt, "Microbodies/Peroxisomen pflanzlicher Zellen." Springer-Verlag, Berlin and New York, 1978.

s A. H. C. Huang, T. Moore, and R. N. Trelease, "Microbodies." Academic Press, New York, 1983.

6. C. Bieglmayer, J. Graf, and R. Ruis, Eur. J. Biochem. 37, 553 (1973).

7 A. H. C. Huang and H. Beevers, J. Cell Biol. 58, 379 (1973).

${ }^{8}$ W. Köller and H. Kindl, Arch. Biochem. Biophys. 181, 236 (1977). 